\section{Uncommon Oral Cleft in Wolf-Hirschhorn Syndrome}

Sibele Nascimento de Aquino ${ }^{1}$, Renato A. Machado ${ }^{1}$, Livia Maris R. Paranaíba², Ricardo D. Coletta ${ }^{1}$, Marcos J. Burle de Aguiar ${ }^{3}$, Cassandro Fernandes ${ }^{4}$, Hercílio Martelli Júnior ${ }^{2,4}$

\begin{abstract}
Wolf-Hirschhorn syndrome (WHS) is a syndrome with craniofacial and systemic abnormalities, which is related to $4 p$ deletion. A 3-month old girl with an undiagnosed syndrome was referred for evaluation of the cleft lip and palate. Hypotonia, short stature, cardiac malformation, hypertrophied clitoris, and atypical thumb of both hands was observed. Microcephaly, low-set ear, prominent glabella, downslanting palpebral fissures, a characteristic "Greek warrior helmet" appearance, micrognathia, ears with pits/tags and bilateral incomplete cleft lip apart from incomplete cleft palate were observed as craniofacial findings. With clinical diagnosis of WHS, blood was subjected to karyotyping, which showed a $4 \mathrm{p} 15.2$ deletion, consistent with the condition. Here is reported the case of this WHS patient with an uncommon oral cleft extending the phenotypic spectrum of the disorder. The child was referred to a multidisciplinary team to reparative surgery of the cleft lip and palate. The patient is on regular medical follow-up and will be further assisted by dentists, physical therapists, occupational therapists and psychologists. The genotype-phenotype correlation of the affected patient with previous WSH syndrome reports is described.
\end{abstract}

\author{
'Department of Oral Diagnosis, Dental \\ School, UNICAMP - University of \\ Campinas, Piracicaba, SP, Brazil \\ ${ }^{2}$ Stomatology Clinic, Dental \\ School, UNIMONTES - State \\ University of Montes Claros, \\ Montes Claros, MG, Brazil \\ ${ }^{3}$ Special Genetics Service, Hospital \\ of the Federal University of Minas \\ Gerais, Belo Horizonte, MG, Brazil \\ ${ }^{4}$ Center for Rehabilitation of \\ Craniofacial Anomalies and School \\ of Medicine, José do Rosário Vellano \\ University, Alfenas, MG, Brazil
}

Correspondence: Sibele Nascimento de Aquino, Avenida Limeira, 901, 13414-903 Piracicaba, SP, Brasil. Tel: +55-19-2106-5315. e-mail: sibeleaquino1@yahoo.com.br

Key Words: Wolf-Hirschhorn syndrome, $4 p$ deletion, cleft lip, cleft palate.

\section{Introduction}

Wolf-Hirschhorn syndrome (WHS, OMIM 194190) is a multi-organ syndrome caused by pure deletions or complex rearrangements, mainly unbalanced translocations, of the short arm of chromosome 4, classifying WHS as a contiguous gene syndrome (1). Approximately $20 \%$ of cases have deletions restricted to $4 p 16.3$, representing the most telomeric $5 \mathrm{Mb}$ ( $2 \%$ of the chromosome). The remaining cases are caused by larger deletions that can extend as far as $4 \mathrm{p} 14$ (2).

Minimal diagnostic criteria for WHS phenotype are defined by the association of growth delay, mental retardation, congenital hypotonia, seizures (or EEG anomalies) and typical facial appearance (microcephaly, hypertelorism, proptosis, downturned mouth, and short upper lip and philtrum), which often is described as the "Greek warrior helmet" profile $(3,4)$. Other minor manifestations include eye defects, dental abnormalities, cleft lip and/or palate, hearing loss, and genitourinary and digestive abnormalities $(1,3,5)$. Since both parents had normal chromosomes, familial recurrence of WHS has never been reported, with except for a familial recurrence of a pure $4 p$ deletion in two brothers of a maternal small deletion (4). The extent of the $4 p$ deletion and the occurrence of a double chromosome imbalance are well established prognostic factors in WHS, but seizures are also an independent prognostic factor for the degree of mental retardation (1).

Here, is reported a case of a WHS patient with an uncommon oral cleft that extends the phenotypic spectrum of the disorder. The genotype-phenotype correlation of the affected patient with previous WSH syndrome reports is described.

\section{Case Report}

A 3-month old girl with an undiagnosed syndrome was referred for evaluation and treatment of the cleft lip and palate. The patient was born at preterm after a complicated pregnancy with pre-eclampsia. She was the first child of healthy and non-consanguineous parents. Her mother was 32-year old and her father 33-year old when she was born. Family history was uneventful. The proband's mother had two previous partners, with the first partner she had two sons and a daughter with the second. The three children were clinically normal (Fig. 1). Craniofacial

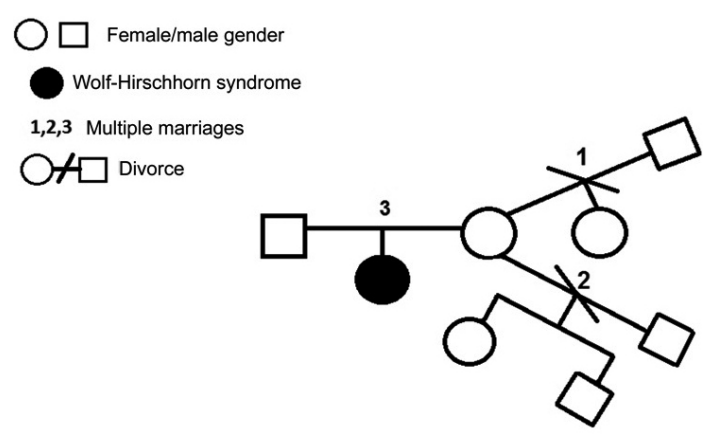

Figure 1. Pedigree of family with WHS. 
abnormalities were characterized by microcephaly, lowset ear, prominent glabella, downslanting palpebral fissures, hypertelorism, exophthalmia, high nasal bridge with a characteristic Greek warrior helmet appearance (Fig. 2A), micrognathia, ears with pits/tags and bilateral incomplete cleft lip apart from incomplete cleft palate (Fig. 2B). Physical examination revealed atypical thumb on both hands (Fig. 2C), hypotonia (Fig. 2D), short stature, cardiac malformation (patent ductus arteriosus) and hypertrophied clitoris. Radiographs suggested bilateral
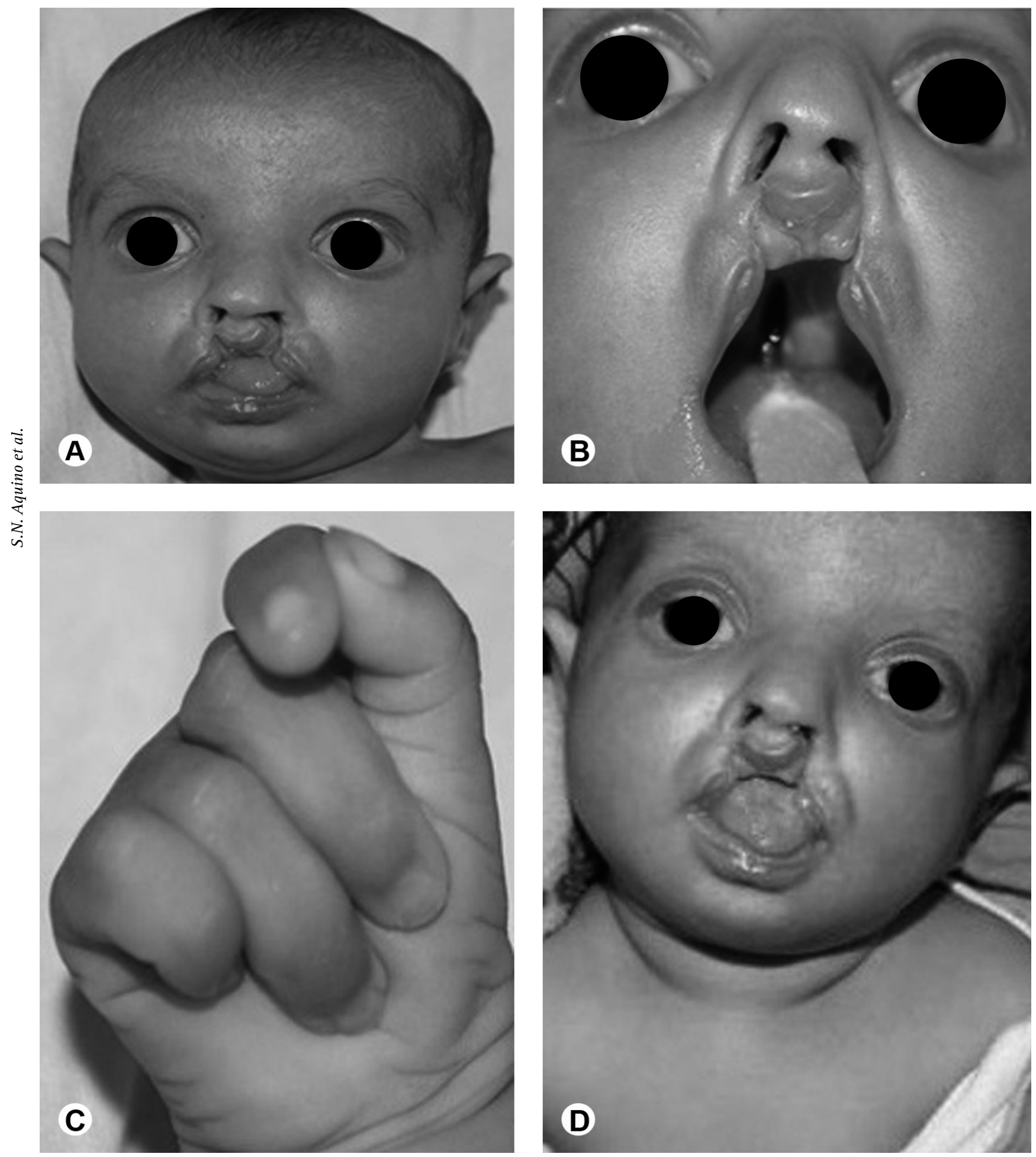

Figure 2. Craniofacial abnormalities including Greek warrior helmet appearance (A) and bilateral incomplete cleft lip and incomplete cleft palate (B). Physical examination of the WHS patient showed atypical thumb (C) on both hands and hypotonia (D). 
hip dislocation.

With a clinical diagnosis of WHS, blood was subjected to karyotyping, which showed a 4p15.2 deletion, consistent with the condition. The patient was referred to a multidisciplinary team to reparative surgery of the cleft lip and palate. The patient is on regular medical follow-up, and later she will be assisted by dentists, physical therapists, occupational therapists and psychologists.

The publication of images of the patient for scientific purposes was authorized by the parents.

\section{Discussion}

Wolf-Hirschhorn (WHS) is a syndrome with a variable expressivity related to the extension of the $4 p$ deletion that ranges from $1.9 \mathrm{Mb}$ to $25 \mathrm{Mb}(3,4)$. It is classically characterized by the constellation of mental retardation, failure to thrive, hypotonia, seizures (or EEG anomalies) and "Greek warrior helmet" facies (3). Specifically, these major manifestations are present in more that $75 \%$ of the affected patients $(3,4)$. Additional malformations, including cleft lip-palate, renal abnormalities, gastrointestinal abnormalities and skeletal abnormalities, are found in less than $50 \%$ of the affected patients $(3,6)$. Besides the typical WHS phenotypes, the current patient showed hypertrophied clitoris, atypical thumbs, bilateral hip dislocation and an uncommon oral cleft (bilateral incomplete cleft lip apart from incomplete cleft palate).

Corroborating previous studies, the severity of the phenotypes was correlated to the deletion extension in the short arm of chromosome $4(4 p 15.3)(3,4,7)$. To date, few WHS patients cases with such extensive deletion have been published. Zollino et al. $(3,4)$ and Ji et al. (8) reported thirteen patients with similar deletions and all of them had severe clinical presentation. Curiously, only four patients had cleft lip and/or palate and to date no patient in the scientific literature showed an uncommon orofacial clefting such as in this case.

Two critical regions have been described in the pathogenesis of WHS (4). WHS critical region 1 (WHSCR1) resides in a 165-kb interval and includes WHS candidate gene 2 (WHSC2, OMIM 606026) and part of WHS candidate gene 1 (WHSC1, OMIM 602952) (9). WHS critical region 2 (WHSCR-2) resides in a 300-600 kb interval defined and includes LETM1 and part of WHSC1 (4). WHSC1 has been determined to be a chromatin remodeling enzyme whose haploinsufficiency causes the facial characteristics and growth delay of WHS, while hemizygosity for LETM1 (leucine zipper/EF-hand containing transmembrane, OMIM 604407), which is a calcium binding protein involved with calcium homeostasis, is responsible for seizure disorders $(7,10,11)$. Moreover, additional other critical regions for co-morbid malformations have been proposed, namely for oligodontia, cleft lip/palate, hypospadia, congenital heart defects, growth retardation and microcephaly $(4,7,12)$. It is important to note that the full phenotypic description of the cases should be encouraged in order to obtain a more accurate presentation of the true relationship between phenotype and genotype in WHS patients and thus to define the characterization of the basic genomic defect.

Life expectancy of WHS patients ranges between 18 and 34 years, depending on the extent of the genetic deletion (2). A constant monitoring with a multidisciplinary approach of their health status seems to improve general well-being and social care thus increasing the survival rate of these subjects (6). In addition, maintenance of good oral conditions may represent an important factor in the quality of life of patients with WHS $(6,13)$. In this clinical report, the girl has been assisted by a multidisciplinary team and primarily, cleft lip surgery has been planned. The patient also has regular medical follow-up because the growth delay and neurological abnormalities represent the greatest problems in clinical management and are important prognostic factors for WHS.

In summary, this case reports unusual features of WHS syndrome and emphasizes the importance of further studies to a better knowledge of the genotype-phenotype correlation of WHS, leading to a more effective diagnosis and treatment of the syndromic patients and helping to understand the molecular mechanisms involved in the pathogenesis of this disorder.

\section{Resumo}

A sindrome de Wolf-Hirschhorn (WHS) é uma condição genética caracterizada por anomalias craniofaciais e sistêmicas, causada por deleção cromossômica na região $4 p$. Paciente de 3 meses de idade, gênero feminino, foi encaminhada para avaliação de fissura de lábio e fissura palatina, associada a uma sindrome não diagnosticada. A paciente apresentava-se com hipotonia, baixa estatura, malformação cardiaca, clitóris hipertrofiado e implantação atípica do polegar nas duas mãos. Microcefalia, baixa implantação da orelha, glabela proeminente, inclinação baixa das fissuras palpebrais, aparência caracteristica de capacete de guerreiro grego, micrognatia, fossetas em orelhas, fissura labial bilateral incompleta e fissura palatina incompleta foram observadas como caracteristicas craniofaciais. Com um diagnóstico clínico de WHS, foi realizado o cariótipo, que mostrou a deleção $4 p 15.2$, consistente com a condição. Esse relato de caso apresenta um caso de WHS, com uma fissura oral incomum, ampliando o espectro fenotípico da doença. A paciente foi encaminhada a tratamento com equipe multidisciplinar para correção cirúrgica da fissura labial e palatina. Encontra-se em acompanhamento médico bem como odontológico, fisioterapêutico e em terapia ocupacional e psicológica. Uma correlação entre genótipo e fenótipo pode ser observada nesse relato da sindrome de WHS.

\section{Acknowledgements}

This work was partially supported by grants from the Minas Gerais State Research Foundation - FAPEMIG to Dr. H Martelli-Junior. SN Aquino is supported by the National Council for Scientific and Technological Development - CNPq, Brasília, Brazil. 


\section{References}

1. Battaglia A, Carey JC, Wright TJ. Wolf- Hirschhorn (4p-) syndrome. Adv Pediatr 2001; 48:75-113.

2. Shannon NL, Maltby EL, Rigby AS, Quarrell OW. An epidemiological study of Wolf- Hirschhorn syndrome: life expectancy and cause of mortality. J Med Genet 2001;38:674-679.

3. Zollino M, Di Stefano C, Zampino G, Mastroiacovo P, Wright TJ, Sorge G, et al.. Genotype-phenotype correlations and clinical diagnostic criteria in Wolf-Hirschhorn syndrome. Am J Med Genet 2000;94:254261.

4. Zollino M, Murdolo M, Marangi G, Pecile V, Galasso C, Mazzanti L, et al.. On the nosology and pathogenesis of Wolf-Hirschhorn syndrome: genotype-phenotype collection analysis of 80 patients and literature review. Am J Med Genet C Semin Med Genet 2008;148C:257-269.

5. Malvestiti F, Benedicenti F, De Toffol S, Chinetti S, Höller A, Grimi B, et al.. Recombinant chromosome 4 from a familial pericentric inversion: prenatal and adulthood Wolf-Hirschhorn phenotypes. Case Rep Genet 2013;2013:306098.

6. Dellavia C, Raiteri S, Ottolina P, Pregliasco F. Oral features in five adult patients with Wolf-Hirschhorn syndrome. Minerva Stomatol 2011;60:391-402.

7. Maas N, Van Buggenhout G, Hannes $F$, Thienpont B, Sanlaville D, Kok K, et al.. Genotype phenotype correlation in 21 patients with
Wolf Hirschhorn syndrome using high resolution array comparative genome hybridisation (CGH). J Med Genet 2008;45:71-80.

8. Ji TY, Chia D, Wang JM, Wu Y, Li J, Xiao J, et al.. Diagnosis and fine localization of deletion region in Wolf-Hirschhorn syndrome patients. Chin Med J 2010;123:1663-1667.

9. Wright TJ, Costa JL, Naranjo C, Francis-West P, Altherr MR. Comparative analysis of a novel gene from the Wolf-Hirschhorn/PittRogers-Danks syndrome critical region. Genomics 1999;59:203-212.

10. Izumi K, Okuno H, Maeyama K, Sato S, Yamamoto T, Torii $C$, et al.. Interstitial microdeletion of 4p16.3: Contribution of WHSC1 haploinsufficiency to the pathogenesis of developmental delay in Wolf-Hirschhorn syndrome. Am J Med Genet Part A 2010;152A:10281032.

11. Okamoto N, Ohmachi K, Shimada S, Shimojima K, Yamamoto T. 109 kb deletion of chromosome 4p16.3 in a patient with mild phenotype of Wolf-Hirschhorn syndrome. Am J Med Genet A 2013;161:1465-1469.

12. Nieminen $P$, Kotilainen J, Aalto $Y$, Knuutila $S$, Pirinen $S$, Thesleff I. MSX1 gene is deleted in Wolf-Hirschhorn syndrome patients with oligodontia. J Dent Res 2003;82:1013-1017.

13. Johnston NJ, Franklin DL. Dental findings of a child with WolfHirschhorn syndrome. Int J Paediatric Dent 2006;16:139-142.

Received January 18, 2014 Accepted October 28, 2014 